\title{
Hybrid Model of Increasing Consumers Activities on Private Universities at Jakarta
}

\author{
Wilhelmus Hary Susilo \\ Departement of Postgraduate, Doctoral Program, Faculty of Economics University of Persada Indonesia Y.A.I, \\ Diponegoro 74, Central Jakarta, Indonesia
}

Abstract

The model inquiry for an effect of marketing mix and the best service quality on perception of image and the implacations of consumer activities in private universities. The structural equation modelling techniques was conducted applied in survey research method to analysis from 224 respondents in higher education at Jakarta. The resulted indicated that marketing mix variables positively have influenced but not significant on image and consumer activites. The best service quality variable have positively impact and significant leads on image with standardized reggresion weights value $=.706$ and $P$ value .001 . Furthurmore service quality and image variables were indicated that positively impact and significant on consumer activites, with standardized reggresion weights value $=.474$ and .393 than $P$ value .001 . The research structural equation model have the marjinal fit on hybrid model with $X^{2}$ value $=802.07, P_{\text {value }}=.000$, RMSEA $=.101, \mathrm{GFI}=.794$ and $\mathrm{CFI}=.849$.

Keywords: Service Quality, Image, Consumer Activities

\section{Introduction}

The role of higher education in the graduate program of strategic and meaningful customer value for the students in building intellectual community in Indonesia in the future, so institution graduate programs have a high role in the effort to build the competitiveness of Institutional and competitive advantage. Furthermore, according to Kotler and Keller (2016) for the success of future marketing should be holistic, build stronger brands through performance rather than through the promotion and leads electronically as well as through building information and communication systems are superior. The philosophy of the marketing concept (Limakrisna and Susilo, 2012) aims to provide satisfaction to the desires and needs of consumers, so that the concept can be applied marketing is a business philosophy that states that the satisfaction of customer needs is a prerequisite for the economic and social viability of the institution, in order to make a profit.

\subsection{Marketing Mix and Service Quality}

In the service of educational institutions should pay attention tostakeholders/stakeholeder potentially consist of 16 (sixteen) "major publics", individuals and groups are very influential in the university (Kotler et al, 1995). Alma (2005) states the elements of the marketing mix strategy in education services consist of traditional 4P and 7P namely 3P again in marketing services. Furthermore, marketing a successful future must be more holistic and has a slim departments (Kotler and Keller, 2016). The role of marketing is not just relying on the promotion and advertising of various kinds and in large numbers, but the performance marketing is becoming a main stay of superior. Then, according to research findings, Viacava (2010) in higher education management in complex human characteristics needed perspective and potentials that develop in human thinking as logically automatic data processor for logic that can be developed to take into account the interaction between emotion and cognition and the environment. Marketing orientation of higher education institutions according to Wright (2012), the marketing literature describes the four types of marketing orientation, colleges and universities should be fully aware of the potential benefits and costs of each type of orientation. On the marketing orientation of a college or university can have a significant impact on all aspects of the marketing strategy.

To create good quality care requires a planning framework and strategic analysis and to achieve that the dimensions of service quality, there are five dimensions service quality by Lovelock (2012), quality of care consists of five dimensions of service quality known as: 1) Reliability, the ability to carry out the promised service reliably and accurately. 2)

Responsiveness, willingness to help customers and provide services quickly, 3) Assurance, knowledge and courtesy and their ability to convey trust and confidence. 4) Empathy, willingness to provide depth and special attention to each customer. 5) Tangibles, physical appearance, equipment, and employee communication materials. Then the good quality 
of service will have a positive impact as follows; established a long-term mutually beneficial relationships, opening up opportunities business growth through repeat purchases, the formation of customer loyalty, the impression of positive word of mouth to attract new customers to the increase in the number of graduate students, and the public perception of the customers who were positive for higher education institutions and increasing competitiveness globally. Then the quality of services is a reflection of updating programs on the four Ps, stated by Kotler and Keller (2016) in the renewal of the marketing mix idea. Furthermore, according to Lovelock and Wright (2005) the quality of services is a cognitive evaluation of long-term delivery of services to the customers of a company. The main objective in improving the quality of services is to reduce the gap that is the overall value customer. On the theory of five (5) most important dimension of quality of services includes, Faganel \& Macur (2006): 1. Reliability. 2. Responsiveness., 3. Assurance., 4. Empathy., 5.Tangibles.

\subsection{Image of the Institution and Consumers Activities}

The consumers buy something, not just a need that stuff, but there is something else to be expected. According to Kotler and Keller (2016), Buyer decides an offer with the delivery of the most superior value. Value is the center of the marketing concept which mainly comes from a combination of quality, service and price. The image can be reflected through brand equity, value-added services provided by the institutions, and consumers is reflected through thoughts, feelings and activities of consumers in respect of the institution, the appropriate level of good perception of price, market share and the level of benefits provided. Furthermore, something else was in accordance with the image formed in him. Therefore, it is important to inform the public organizations in order to establish a good image (Alma, 2005). Sutojo (2004) says that the company has a good image and strong benefits; (1). Strong competitiveness in the medium and long term, (2). Provide protection during the crisis, (3). Being reliable attractiveness executive, (4). Improve the effectiveness of marketing strategies, (5). Operational cost savings. Dimensions which is the focus of marketers to consumers' desire for the purchasing actions include: (1). The concept of products and services delivered to consumers. (2). Situations that may affect the purchase by the consumer. (3). Impulse purchases by consumers. (4). Its purchasing actions by consumers. (Bennett, 2010). Furthermore, according to Indrajit \& Djokopranoto (2006) is a customer of the university students who study at the university, where students follow a very intense process that occurs at universities in the manufacture of the product, whether the product is a student himself, learning, mastery of knowledge or education. Students participate in the process, so it affects the quality of the product.

\section{Problem Formulation and Research Objective}

Based on the above, this study in addition to reconfirm the results of previous studies (Yulius, 2004) on the effect of marketing mix of education on the image of private universities and the implications for the number of active students, also test the service quality variables (developed by; Lovelock \& Wright (2005), Lupiyoadi \& Hamdani (2006), Faganel \& Macur (2006), and Alma (2005) on the image of the institution and its implications on the activities of students in the Department of Architecture Faculty of Engineering Private Universities in Jakarta. For this study will try to answer the problems as follows; how does the marketing mix, best service qualities influences to the image of the institution and impact on consumer activities in the Department of Architecture Faculty of Engineering Private Universities in Jakarta?

In connection with the problems that have been formulated, the purpose of this study is: determine the influence of marketing mix, best service qualities to the image of the institution and impact on consumer activities in the Department of Architecture Faculty of Engineering Private Universities in Jakarta.

\section{Conceptual framework and literature}

\subsection{Hybrid Model}

The development of a theoretical model by conducting a series of scientific exploration through literature review in order to obtain a theoretical justification to be developed, it could be seen in figure 1 below:

Figure 1. Theoretical Hybrid Model Development of Consumer Activity Throught the Image of Institutions from Best Service Quality and Marketing Mix in Private Universities in Jakarta 


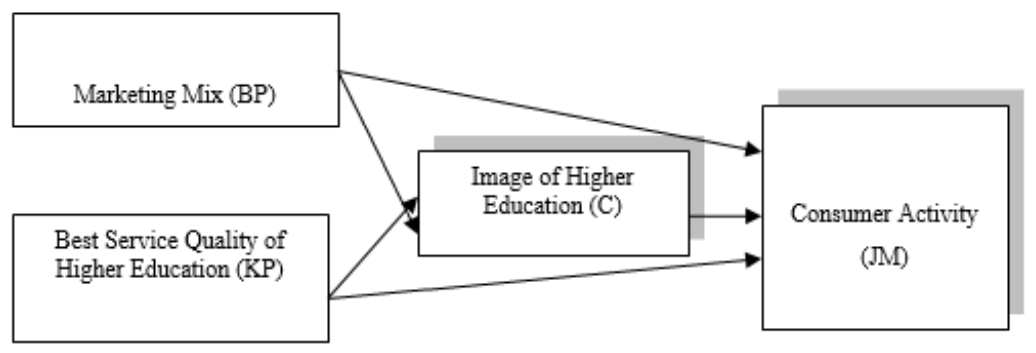

\subsection{Research Hypothesis}

By paying attention to the study of theory and literature as well as reviewing the research framework diagram generated research hypotheses as follows:

\subsubsection{Marketing Mix Influence of Institutional Image}

According to Cetin (2004) university in the face of diverse Issues and challenges of the present, must provide quality higher education to the existence of image quality/good reputation of the university. Meanwhile, according to Kotler (2001) that the marketing mix variables are determinants of corporate image. While the research results Yulius (2004) of the results of empirical research found that the marketing mix affects the image of education in total PTS and the most dominant element is the element of human resources and infrastructure elements of the research materials.

Chattananon, Lawley, Trimetsoontorn (2007) indicate the build image company through social marketing programs and communications companies by creating a positive consumer atitude. Further research findings of Li \& Hung (2009) showed a significant selective marketing tactics and predictable with very significant on the school's image. Promotion Tactics is a strategy that is most effective prediction of the behavior of parents. Finally the image of the school as a mediator of the relationship between parent and loyalty marketing tactics. Based on these descriptions, the hypothesis can be formulated as follows:

$\mathrm{H}_{1}$ : services marketing mix affects the image of the institution in the Department of Architecture Faculty of Engineering at Private University in Jakarta.

\subsubsection{Effect on Image Quality Service Institution.}

According Lupiyoadi and Hamdani (2006), where gaps in services exist or are not perceived perception of perceived customer and customers expect the same proven, then the company will acquire the image and positive impact.

Meanwhile, according Ruyter and Wetzels (2000), in experimental studies show long-term care better affect the image. Then according Gronroos (1984) dimensions of service quality related and an important feature of an image. A review of Nguyen \& LeBlanc (1998) indicated a positive influence on the quality of services to the formation citra.Selanjutnya according Gurbuz (2008) service quality affects the product image. Based on these descriptions, the hypothesis can be formulated as follows:

$\mathrm{H}_{.2}$ : service quality affects the image of the institution in the Department of Architecture Faculty of Engineering at Private Universities in Jakarta.

\subsubsection{Marketing Mix Influence of Consumer Activities}

In the model of supply of higher education services according to Alma (2005) and the results of research Yulius (2004), shows the marketing mix affects the increase in the number of applicants, ie applicants service users. Meanwhile, according to Bennett (1997), there is a relationship between the marketing mix with the purchase process. Later testing of Ndubisi (2007) showed a significant effect on the relationship between marketing strategy customer loyalty. Further arguments from Harvey (1996) on marketing in schools and educational institutions are expected to attract college students. According to Rosenberg \& Czepiel (1984) Marketers arrange special marketing mix and marketing organizations modifications and create a balance between the marketing performance of new and old customers to 
improve profit growth. Then, according to Judd (2003) marketing mix can help in consumer-oriented institutions to produce a competitiveness through differentiation and provide value to the customer. While the research results Eusebio et al., (2006), found that an effective marketing strategy occurs in the orientation towards customers. Based on these descriptions, the hypothesis can be formulated as follows:

$\mathrm{H}_{.3}$ : Marketing mix affects the activity of students in the Department of Architecture Faculty of Engineering at Private Universities in Jakarta

\subsubsection{Effect of Service Quality of Consumer Activities}

According to Alma (2005) on the model of supply of higher education services, required quality of service for customer satisfaction that will increase the number of applicants. Furthermore, according to Bloemer, Ruyter and Peeters (1998) were an important influence on the reliability dimension or dimensions of quality to customer loyalty. Also according Gurbuz (2008) states in its findings that a positive perception of service quality effect on the loyalty costumers. Furthermore, according Li et al., (2009) empirical research results, indicating a positive effect of the quality of services to customers. Based on these descriptions, the hypothesis can be formulated as follows:

H.4: service quality affect the activity of students in the Department of Architecture Faculty of Engineering at Private Universities in Jakarta.

\subsubsection{Effect of Image Institution of Student Activities}

According to Nguyen \& LeBlanck (1998) image of a strong positive impact on trust costumers. According to Bloemer, Ruyter and Peeters (1998) dimensions of the image affects customer loyalty. In accordance with the opinion from Andreassen and lindestad (1998) that the direct effect of the image on customer loyalty. Furthermore, the opinion of Russell (2005), the image becomes the most important consideration for the consideration of decision making by students for course selection and learning place. Based on these descriptions, the hypothesis can be formulated as follows:

$\mathrm{H} .5$ : The image of the institution influence the activity of students in the Department of Architecture Faculty of Engineering at Private Universities in Jakarta.

\section{Data and Methodolgy}

An analysis hybrid model conducted in this study is Structural Equation Modeling (SEM). SEM used in this study because it has the ability to confirm the dimensions or indicators of a concept of latent variables, as well as to measure the relationship between variables that have been supported by theory and empirical research (Hasnawati, 2005). Structural equation modeling using latent variables by the number of indicators that many theoretical terms it is better because it will be able to explain the measurement error in the model be better. (Ghozali, 2008). Given in this study the number of indicators a lot of the questions are: 1. Variable of services marketing mix has 49 indicators, 2. Variable of quality of service has 86 indicators, 3. Variable of image of the institution has 18 indicators and 4. Variable of activity students have 12 indicators. So one way to overcome this is to estimate the model with a single indicator composite SEM with AMOS 16.0. (Ghozali, 2008). Structural equation formulated to express causality between different constructs as below in equation 1 and 2 :

$$
\begin{aligned}
& C=\gamma .1 B P+\gamma .2 \mathrm{KP}+\zeta .1 \\
& J M=\gamma .3 \mathrm{BP}+\gamma .4 \mathrm{KP}+\beta .1 \mathrm{C}+\zeta .2
\end{aligned}
$$

Equation specification measurement model: a variable that measures the constructs defined and define a set of matrices that show the correlation between the hypothesized constructs or variables. Evaluate structural components hypothesized causal relationships among latent variables in a causal model and show an entire hypothesis testing of the model as a whole. 


\section{Structural Equation Specification Notation:}

$\begin{array}{ll}\text { Num } & \text { Notation } \\ 1 & \mathrm{BP} \\ 2 & \mathrm{KP} \\ 3 & \mathrm{C} \\ 4 & \mathrm{JM} \\ 5 & \Gamma \text { (gamma) } \\ 6 & \mathrm{~B} \text { (Beta) } \\ 7 & \mathrm{Z} \text { (ZETA) } \\ 8 & \Lambda \text { (Lamda) } \\ 9 & \mathrm{E}\end{array}$

\section{Results}

\subsection{Normality Evaluation Data and Data Outliers}

According Ghozali (2008) method of maximum likelihood (ML) calls for the assumptions that must be met, namely the distribution of observed variables is multivariate normal. In multivariate value 177.927 is the coefficient of multivariate kurtosis with 37.690 critical value whose value is above 2.58 , so the data are not multivariate normal. For that were estimated by a bootstrap procedure. In the original model without bootstrap value of chi-square $=562.888$, with a probability of 000 . While the results of the probability value Bollen-Stine bootstrap $p=.000$ is significant that these results remain consistent.

Evaluation of multivariate outliers is necessary because although the data were analyzed showed no outliers in univariate level, but it can be observasi- observation outliers. Distance mahalonobis to among variables could be calculated and will show a variable distance from the mean of all variables (Ferdinand, 2005). Mahalanobis distance calculation is based on the value of the chi-square distribution table $x^{2}$ the degrees of freedom by 24 (the number of sub-variables) at the level of $p<0.001$ ie $=42.980$. Therefore, data with Mahalanobis distance is less than 42,980 are considered multivariate outliers occur. Based on multivariate outliers evaluation, there are 25 observations have a value greater from Mahalanobis Distance value of 42.980 , but in this study the observations are not excluded from the model, because in the analysis of the results of the study, if there is a specific reason to remove the case indicates the presence of outliers, then the case must still be included in the subsequent analysis.

\section{Analysis of Hybrid Model}

An output of the hybrid model in this study can be seen in figure 2 below:

Figure 2. Hybrid Model Outcomes of Consumer Activity (JM) Throught the Image of Institutions (C) from Best Service Quality (KP) and Marketing Mix (BP) in Higher Education 


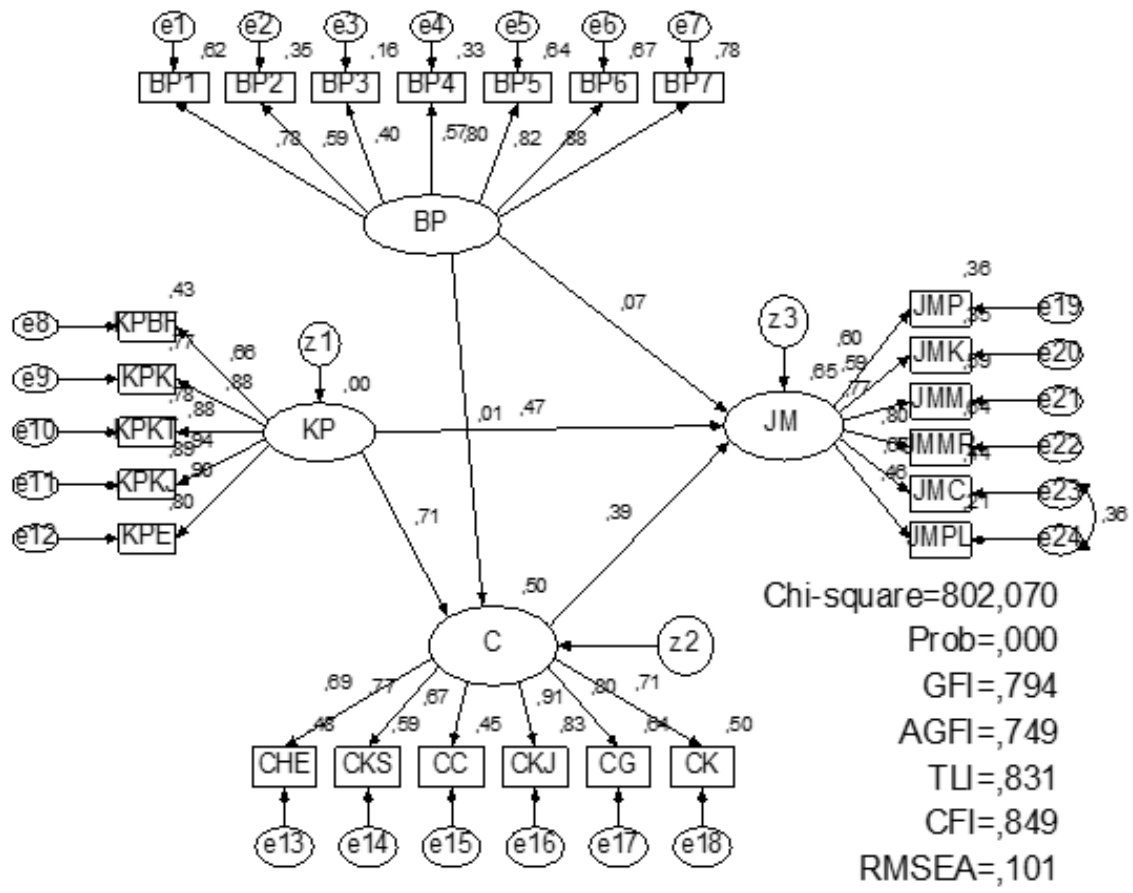

Source: Primery data processed

Furtheremore an evaluation criteria of empirical research of level of the fitting hybrid models, could be seen in table 1 empirical model evaluation criteria below:

Table 1. Empirical Model Evaluation Criteria

\begin{tabular}{lllll}
\hline Num & Criteria & Cut-of Value & Result of Model & Model of Evaluation \\
\hline $\mathbf{1}$ & Chi-square & $\begin{array}{l}\text { Be hope of small ( } 0=\text { value of fit } \\
\text { complete) } \\
\geq 0.05\end{array}$ & 802.070 & It is not very good fit model \\
$\mathbf{2}$ & Probablity &, 000 & $\begin{array}{l}\text { Covariance matrix } \\
\text { difference between the } \\
\text { population and the } \\
\text { example is significant. }\end{array}$ \\
$\mathbf{3}$ & GFI & $\geq 0.90$ & Marjinal \\
$\mathbf{5}$ & AGFI & $\geq 0.90$ & 0.794 & Marjinal \\
$\mathbf{6}$ & TLI & $\geq 0.90$ & 0.749 & Marjinal \\
$\mathbf{7}$ & RFI & $\geq 0.90$ & 0.831 & Marjinal \\
\hline
\end{tabular}

Source: Output Model conducted by AMOS (primary data processed)

Estimates of the criteria (Absolute Fit Measure) and evaluation of influence coefficients between variables on path. ChiSquare $\left(\mathrm{X}^{2}\right)$, chi-square value of 802.07 and is significant at the 0.000 probability. The significance level was below the criteria for .05. The information indicated that the difference between the covariance matrix of the sample population is significant. Chi-square values are high relative to the degree of freedom (246), shows that the covariance or correlation matrix of the observed with the predicted differ significantly and this results in the probability $(p=0.000)$ less than the level of significance, therefore, test the accuracy of the model with a value based on Chi-Square categorized excluding 
very good fit. GFI - Goodness Fit Index, a measure of non-statistical value ranging from 0 (poor fit) until 1 (perfect fit). GFI values generated in this study is .749, the value of GFI is below the acceptance criteria is GFI $\geq .90$. The magnitude of this value shows only marginal support to the theoretical model.

Path coefficients (standardized regression) Effect of inter-variable, to test the hypothesis presented that show the influence of the path coefficients between variables, can be seen in Table 2 below:

Table 2. Coefficient of Path (Standardized Regression) Effect of inter-variable and $P$ value

\begin{tabular}{llll}
\hline Num & Path & $\begin{array}{l}\text { Estimate (Standardized } \\
\text { Reggresion Weights) }\end{array}$ & P. value \\
\hline $\mathbf{1}$ & $\mathrm{BP} \rightarrow \mathrm{C}$ &, 007 &, 939 (not significant at .05) \\
$\mathbf{2}$ & $\mathrm{KP} \rightarrow \mathrm{C}$ &, 706 & ${ }^{* * *}$ (significant at .001) \\
$\mathbf{3}$ & $\mathrm{BP} \rightarrow \mathrm{JM}$ &, 068 &, 456 (not significant at .05) \\
$\mathbf{4}$ & $\mathrm{KP} \rightarrow \mathrm{JM}$ &, 474 & ${ }^{* * *}$ (significant at .001) \\
$\mathbf{5}$ & $\mathrm{C} \rightarrow \mathrm{JM}$ &, 393 & ${ }^{* * *}$ (significant at .001) \\
\hline
\end{tabular}

Source: Output AMOS 16.0 (Primary Data processed)

\section{Discussion and conclution}

\subsection{Empirical Model Hypothesis Testing}

This research study would be proposed five hypotheses of four variables, namely; superior marketing mix (BP), best quality of service (KP), the well image of the institution (C) and harder consumer activities (JM) in the Architecture Faculty of Engineering at Private Universities in Jakarta. This hypothesis is estimated by the maximum likelihood estimates in the structural model, the path coefficients (standardized regression) between variables and the effect of the $\mathrm{P}$ value.

\subsubsection{Empirical Model Hypothesis Testing.}

Hypothesis 1 is proposed marketing mix affects the image of the institution in the Architecture Faculty of Engineering programs willing private university in Jakarta. Marketing mix variables constructed by seven dimensions pertains: (1) Product service (BP1), (2) Cost of services (BP2). (3) The location of services (BP3), (4) Promotion of services (BP4), (5) Officer services (BP5), (6) Infrastructure services (BP6), (7) Process services (BP7). While the well image of the institution in a variable environment of Architecture Faculty of Engineering courses in private universities in Jakarta built by six dimensions which include: (1) The perception of trust (CK), (2) Ideas (CG), (3) perceptions of performance (CKJ), (4) image Perception (CC), (5) perception of the impression (CKS), (6) emotional relationship (CHE). The effect of superior marketing mix variables on the well image of the institution is positive with a value of estimate (standarized reggresion weights) of .007 and not significant at $P$ value $=$ value .939 (the value is far above the significant level at .05), so the hypothesis 1 can not be confirmed.

Hypothesis two proposed is the best service quality affects the well image of the institution in the study program of Architecture, Faculty of engineering, private university in Jakarta. Variable of quality of service built by five measurement dimensions which include: (1) Dimensions of physical evidence (KJBF), (2) Dimensions Reliability (KJK), (3) responsiveness dimension (KJKT), (4) Dimensions assuredness (KJKJ), (5) Dimensions of Empathy (KJE). While the well image of the institution in a variable of environment of Architecture Faculty of Engineering at Private Univeristies in Jakarta built by six indicators of measurement include: (1) The perception of trust (CK), (2) Ideas (CG), (3) perceptions of performance (CKJ), (4 ) image Perception (CC), (5) perception of the impression (CKS), (6) emotional relationship (CHE). The effect of the variable of services quality is a positive well image of the institution with a value estimate (standarized reggresion weights) of, 706 and significant at a $\mathrm{P}$ value value $={ }^{\star \star \star}$ (significant at the .001 value) thus hypothesis 2 can be confirmed.

Hypothesis three is proposed superior marketing mix affects the harder activity of students in the Architecture Faculty of Engineering courses, private university in Jakarta. Marketing mix variables constructed by seven dimensions include: (1) Product service (BP1), (2) Cost of services (BP2). (3) The location of services (BP3), (4) Promotion of services (BP4), (5) 
Officer services (BP5), (6) Infrastructure services (BP6), (7) Process services (BP7). While the student activity variables in the environment of Architecture Faculty of Engineering courses in private universities in Jakarta built by six indicators of measurement include: (1) Academic activities (AMP), (2) non-academic activities (MCA), (3) The recommended (AMM), (4) Assess the reputation (AMMR), (5) customer intelligence level (AMC), (6) environmental influences (AMPL). The effect of marketing mix variables on the activity of the students is positive with a value of estimate (standarized reggresion weights) of, 069 and not significant at $P$ value $=$ value .456 (the value is far above the significant level at .05), so the hypothesis 3 can not be confirmed.

Hypothesis four proposed is superior service quality affects the student activities in the Architecture Faculty of Engineering courses, private university in Jakarta. Variable quality of services in the Architecture Faculty of Engineering courses in private universities in Jakarta built by five measurement dimensions which include: (1) The dimensions of physical evidence (KJBF), (2) Dimensions Reliability (KJK), (3) responsiveness dimension (KJKT), (4) Dimensions assuredness (KJKJ), (5) Empathy Dimension (KJE). While the student activity variables in the environment of Architecture Faculty of Engineering at Private universities in Jakarta built by six indicators of measurement include: (1) Academic activities (AMP), (2) non-academic activities (MCA), (3) The recommended (AMM), (4) Assess the reputation (AMMR), (5) customer intelligence level (AMC), (6) environmental influences (AMPL). The effect of service quality variables on the activity of the students is positive with a value of estimate (standarized reggresion weights) of .474 and significant at a $P$ value $={ }^{* * *}$ (significant at the .001 value), thus hypothesis 4 can be confirmed.

Hypothesis five proposed is the well image of the institution influence the harder activity of the students in the courses of Architecture, FT, Private Universities in Jakarta.Variabel Image institutions built by the six dimensions of measurement include: (1) The perception of trust (CK), (2) Ideas (CG) , (3) Perceptions of performance (CKJ), (4) Perception of image (CC), (5) Perception of the impression (CKS), (6) Emotional relationship (CHE). While the student activity variables in the environment of Architecture Faculty of Engineering at Private universities in Jakarta built by six dimensions of measurement include: (1) Academic activities (AMP), (2) Non-academic activities (MCA), (3) The recommended (AMM), (4) Assess the reputation (AMMR), (5) Customer intelligence level (AMC), (6) Environmental influences (AMPL). The well image of the institution variable influence on the activity of the students is positive with a value of estimate (standarized reggresion weights) of .393 and significant at a $P$ value value $={ }^{* * *}$ (significant at the .001 value) thus hypothesis 5 can be confirmed.

Further statistical conclusions on the research hypothesis can be seen in table 3 below:

Table 3. Conclusions of Statistics Value on Hypothesis

\begin{tabular}{lllll}
\hline No & Hypothesis & $\begin{array}{l}\text { Nilai estimate } \\
\text { (standarized } \\
\text { reggresion } \\
\text { weights) }\end{array}$ & P Value & $\begin{array}{c}\text { conclusion } \\
\text { Statistics }\end{array}$ \\
\hline $\mathbf{1}$ & $\begin{array}{l}\text { The hypothesis proposed is a marketing mix affects } \\
\text { the image of the institution in the Architecture Faculty } \\
\text { of Engineering programs willing private university in } \\
\text { Jakarta. }\end{array}$ & .007 & .939 & $\begin{array}{l}\text { Positive and not } \\
\text { significant }\end{array}$ \\
\hline $\mathbf{2}$ & $\begin{array}{l}\text { Hypothesis two proposed is an effect on the image } \\
\text { quality of the services in the study program of } \\
\text { Architecture, Faculty of engineering, PTS in Jakarta. }\end{array}$ & .706 & at .001) & Positive and \\
significant
\end{tabular}

(Source: processed primary data) 


\subsubsection{Discussion of Research Model}

Based on the test results and test the suitability of statistical, empirical models in this study as a whole can not be said to be a very good fit model but not a very good fit model. This happens because the results of the reference values and criteria in conformance testing and statistical test models are: Chi-square value evaluation model that does not produce a very good fit model and the probability value ( $P$ value) which is the covariance matrix between populations and sample is significant. Values of GFI, AGFI values, values TLI and CFI values produce marginal evaluation model. While the RMSEA value is the evaluation of the model is not a very good fit model. The model is a very good fit can not be presented in this research model is none other than because the data generated in this study are very diverse, both data between variables or data in a variable itself.

Results of this study was known that the superior marketing mix and not a significant positive effect on the well image of the institution in the Architecture Faculty of Engineering at Private Universities in Jakarta, so the first hypothesis failed to be confirmed (rejected). According to Cetin (2004) university in the face of a multitude of issues and challenges in today's era of applying high quality education, university image and marketing system and with regard to relevant stakeholders. Furthermore, according to Kotler (2001) that the marketing mix variables are determinants of corporate image. Results of testing hypothesis 1 does not support the results of research conducted by Yulius (2004) of the results of empirical research found that the marketing mix affects the image of education in total Private Universities and the most dominant element is the element of human resources and physical infrastructure elements. The results of this study do not support the findings; of research Chattananon et al., (2007) indicates build corporate image through social marketing programs and communications companies by creating a positive consumer attitude. Further research findings of Li \& Hung (2009) showed a significant selective marketing tactics and predictable with very significant on the school's image. Promotion Tactics is a strategy that is most effective prediction of the behavior of parents. Finally, the image of the school as a mediator of the relationship between parent and loyalty marketing tactics. There is consistency in the results of this study with previous research studies showed that the application of the marketing mix does not contribute directly to the institution's image in the Architecture Faculty of Engineering Private Universities in Jakarta.

Hypothesis 2 can be confirmed that the best quality of services and significant positive effect on the well image of the institution in the Architecture Faculty of Engineering at Private Universities in Jakarta. The results are consistent with the opinion according Lupiyoadi and Hamdani (2006), where the gaps in service provision does not exist, then the company will acquire the image and positive impact. The results of this study support previous studies in which the results of the study indicated that the best service quality positively and significantly related to the well image of the institution. The best quality of service is found a positive effect on the image of the banking institution (Nguyen \& LeBlanc, 1998).

Furthermore, according Gronross (1984) dimensions of quality-related and very important in the image. Meanwhile, according Ruyter and Wetzels (2000), in experimental studies show long-term care better affect the image. The results of this study also support the research of Gurbuz (2008) service quality affects the product image. Consistency in the results of this study with the results of previous studies showed that the application of the best quality services contribute directly to the institution's well image in the Architecture Faculty of Engineering at Private Universities in Jakarta.

The results of this study are three known hypothesis can not be confirmed (rejected) is the superior marketing mix and not a significant positive effect on the harder student activity programs within the Department of Architecture Faculty of Engineering Private Universities in Jakarta. The results of this study do not support the results of previous studies that the total marketing mix affects the number of the harder active students (Julius, 2004). Furthermore, according to Alma (2005) on the model of supply of higher education services, in which the marketing mix affect the number of applicants are university students service users. Then according to Bennett (1997) the marketing mix affects the buying process and Harvey (1996) argues methods and ideology of the commercial marketing is very appropriate to be applied by a professional role in educational institution/University which is expected to attract students. Later testing of Ndubisi (2007) showed a significant effect on the relationship between marketing strategy customer loyalty. Besides, this study does not support the thesis according to Rosenberg \& Czepiel (1984) Marketers arrange special marketing mix and marketing organizations modifications and create a balance between the marketing performance of new and old customers to improve profit growth. The results of this study do not support previous studies by Judd (2003) marketing mix can help in a consumer-oriented institution to produce a competitiveness through differentiation and provide value to the customer. While the research results Eusebio et al., (2006), found that an effective marketing strategy occurs in the orientation 
towards customers. With the results of this study do not support previous studies of the marketing mix does not contribute directly to the activities of students in the Architecture Faculty of Engineering Private Universities in Jakarta

Four hypotheses can be confirmed that the best quality of services and significant positive effect on the harder student activities in the Architecture Faculty of Engineering at Private Universities in Jakarta.

These findings imply the existence and improvement of quality of service (dimensions of physical evidence, the dimensions of reliability, responsiveness, and empathy assuredness) will be able to increase the harder activity of students (lecture, non-academic activities, recommend, assess the reputation of the institution, "the customer becoming harder to please" and environmental influences) in the Architecture Faculty of Engineering at Private Universities in Jakarta. This study supports the notions according to; Alma (2005) on the model of supply of higher education services, quality of service to customer satisfaction will increase the number of applicants that prospective service users as of output. Meanwhile, the opinion of Russell (2005) In evaluating the perception of quality of service on international students, the university requests to adopt marketing strategies to increase the number of international student population and increase revenue. In line with the thinking of Bennett (2010), marketers must understand the process that consumers make purchases of goods or services in relation to the use of marketing mix strategy successfully. The marketing mix is up to date to cover; people, processes, programs and performance Institution. Furthermore, according to Kotler and Keller (2016) who stated marketing will work well if personnel in the organization has a strong commitment and also reflects marketers to understand consumers better and more widely, not just the purchase of goods and services. According Stimac and Simic (2012) strategy that can be applied to institutions of higher education; form a marketing department, marketing tools that should be used to promote the institution: publicity, web marketing, public relations, direct marketing aimed at students of potential current and former students to enhance the image and reputation of higher education institutions.

Furthermore, according to Bloemer, Ruyter and Peeters (1998) were an important influence on the reliability dimension or dimensions of quality to customer loyalty. In addition, this study also supports research by Gurbuz (2008) states in its findings that a positive perception of service quality effect on customer loyalty. Furthermore, the results of this study support the research conducted by Li et al., (2009) empirical research results, indicate a positive influence of the quality of customer service. With the inconsistency of the results of this study with previous research studies, the quality of the services contribute directly to student activities in the Architecture Faculty of Engineering at Private Universities in Jakarta. Consumers have the intention to buy will be very subjective, uncertain and have alternative choices of goods and services. Based on research and internal and external influences, marketers often ask consumers about buying intentions of consumers to be able to predict sales. Dimension which is the focus of marketers to consumers' desire for the purchasing actions include: (1). The concept of products and services delivered to consumers. (2). Situations that may affect the purchase by the consumer. (3). Impulse purchases by consumers. (4). Its purchasing actions by consumers. (Bennett, 2010)

Five hypotheses can be confirmed that the image of the institution positive and significant effect on the activity of the students in the Architecture Faculty of Engineering at Private Universities in Jakarta. These findings indicate the existence and the increase in the institution's well image FT Private Universities Architecture courses in Jakarta will be able to increase the more harder activity of students in the Architecture Faculty of Engineering at Private Universities in Jakarta. The results of this study support previous studies of Julius (2004) image of the Private Universities affects the number of active students, but the effect is relatively small. Besides, the results of this study also support the notions according to; Russell (2005) the reputation of Bournemouth University tourism courses is very important for students to take the decision to choose a course. Then Bloomer opinion, Ruyter and Peeters (1998) Dimensions of the image on the market positioning is very important relative to control retail banking customer loyalty. Furthermore, according to Andreassen \& Lindestad (1998) coorporate image affects directly to the customer loyalty. According to Nguyen \& LeBlanck (1998) image of a strong positive impact on customer confidence. With the inconsistency of the results of this study with the results of previous research studies, the well image of the institution directly contribute to the more harder student activities in the Architecture Faculty of Engineering at Private Universities in Jakarta.

\subsubsection{Conclutions}

Based on the analysis and discussion that has been described, it can be concluded that; superior marketing mix and not a significant positive effect on the well image of the institution in the Architecture Faculty of Engineering at Private Universities in Jakarta, so the first hypothesis failed to be confirmed (rejected) and the findings of these results, the 
findings of this debilitating mix theory services marketing. Based on these findings mean marketing mix but the positive effect is relatively small so it does not significantly influence the image of the institution that needs to improve and optimize the dimensions of the superior marketing mix variables which include; process of educational services, physical infrastructure, education services officer, product education services, the cost of education, location services education and promotion services.

The best quality of service and significant positive effect on the well image of the institution in the Architecture Faculty of Engineering Private Universities in Jakarta, so the second hypothesis can be confirmed, and the findings of this study, these findings reinforce the theory of service quality. Based on these findings mean the best service quality can be improved by optimizing the well image of the institution. Marketing mix and not a significant positive effect on the more harder student activity programs within the Department of Architecture Faculty of Engineering Private Universities in Jakarta, so hypothesis 3 confirmed failure (rejected) and the findings of this study, these findings undermine theories marketing services mix. Based on these findings mean marketing mix but the positive effect is relatively small so it does not significantly influence the more harder activity of the students, so it needs to improve and optimize the dimensions of the marketing mix variables which include; process of educational services, physical infrastructure, education services officer, product education services, the cost of education, location services education and promotion services.

The best quality of services and significant positive effect on the more harder activity of the students in the study program Architecture FT Private Universities in Jakarta, so hypothesis 4 can be confirmed and the findings of this study, these findings reinforce the theory of service quality. Based on these findings mean the best of service quality can be improved by optimizing the more harder activity of students. The well image of the institution positive and significant effect on the more harder activity of the students in the Architecture Faculty of Engineering courses in private universities in Jakarta, so hypothesis 5 can be confirmed and based on the findings of this research, these findings reinforce the image of the institution theory. Based on these findings provide the well image of the institution can be improved by optimizing the more harder activity of students. To be able to improve significantly the purchaser at an educational institution, it can improve the best quality of services with consideration; assuredness, empathy, responsiveness, reliability and physical evidence.

\section{References}

[1] Alma, Buchari, (2005), Manajemen Pemasaran dan Pemasaran Jasa. Bandung: Alfabeta CV, Cetakan ketujuh ( Edisi Revisi), 2005.

[2] Alma, Buchari, (2005), Pemasaran Startejik Jasa Pendidikan. Bandung: Alfabeta CV, Cetakan Kedua, 2005.

[3] Andreassen, Tor Wallin., and Lindestad, Bodil (1998), " Customer Loyalty and Complex Services: The Impact of Corporate Image on Quality, Customer Satisfaction and Loyalty for Customers with Varying Degrees of Service Expertise", International Journal of Service Industry Management, Vol: 9, Issue: 1, p. 7-23.

[4] Bennett, Anthony R, (1997), "The Five Vs- a Buyer"s Perspective of the Marketing Mix", Journal Marketing Intelligence \& Planning, Vol. 15, Issue: 3, p.151- 156.

[5] Bennett, Anthony G. (2010). The Big Book of Marketing, Lessons and Best practices from the World's Greatest Companies, New York, The McGraw -Hill Companies..

[6] Bloemer, Josee., and Ruyter, Ko de., and Peeters, Pascal, (1998), "Investigating Drivers of Bank Loyalty: the Complex Relationship Betweeen Image, Service Quality and Satisfaction", International Journal of Bank Marketing, Vol.16, Issue: 7, p.276- 287.

[7] Cetin, Rubeena, (2004), "Planning and Implementing Institutional Image and Promoting Academic Programs in Higher Education", Journal of Marketing for Higher Education, Vol.13.

[8] Chattanannon, Apisit., Lawley, Meredith., Trimetsoontorn, Jirasek., Supparerkchchaisakul, Numchai., and Leelayouthayothin, (2007), "Building Corporate Image Throught Societal Marketing Programs", Journal Society and Business Review, Vol.2, Issue: 3, p.230- 253. 
[9] Eusobio, Rossano., Andreu, Joan., and Belbeze, M. Pilar Lopez, (2006), "Measures of Marketing Performance: a Comparative Study from Spain", International Journal of Contemporary Hospitality Management, Vol: 18, Issue: 2, p. 145- 155.

[10] Faganel, Armand., and Macur, Mirna, (2006), "Competing Through Quality in Higher Education: The Case of Faculty of Management Koper", University of Primorska Slovenia, http://www2.fm-kp.si/zalozba//SBN/9616486- 71--3/ 125-139.pdf.

[11] Ferdinand, Augusty, (2005), Structural Equation Modeling dalam Penelitian Manajemen, Semarang: Badan Penerbit Universitas Diponegoro.

[12] Gerson, RF, (1994), Marketing Strategy for Small Business, Crip Publication.

[13] Ghozali, Imam., (2008), Model Persamaan Struktural Konsep \& Aplikasi Dengan Program AMOS 16.0, Semarang: Badan Penerbit Universitas Diponegoro.

[14] Ghozali, Imam., dan Fuad., (2005), Structural Equation Modeling ( Teori, Konsep dan Aplikasi dengan Program Lisrel 8.54), Semarang: Badan Penerbit Universitas Diponegoro.

[15] Gronroos, Christian., (1984), "A Service Quality Model and Its Marketing Implications", European Journal of Marketing, Vol.: 18, Issue: 4, p. 36- 44.

[16] Gurbuz, Esen., (2008), "Retail Store Branding in Turkey: its Effect on Percieved Quality, Satisfaction and Loyalty", EuroMed Journal of Business, Vol.: 3, Issue: 3, p.286- 404.

[17] Harvey, Janet A., (1996), "Marketing School and Customer Choice", International Journal of Educational Management, Vol.:10, Issue: 10, p.26- 32.

[18] Hasnawati, S., (2005), "Implikasi Keputusan Investasi, Pendanaan dan Deviden Terhadap Nilai Perusahaan Publik di BEJ", Media Bulanan Manajemen Usahawan Indonesia, No: 09/ TH XXXIV.

[19] Indrajit, Eko R., dan Djokopranoto, Richardus. (2006), Manajemen Perguruan Tinggi Modern, Yogyakarta: C.V ANDI OFFSET.

[20] Joni, T. Raka, (2006), "Mutu Pendidikan, Politik dan Dana", Surat Kabar Harian KOMPAS, 3 Februari.

[21] Judd, Vaughan C., (2003), "Achieving a Customer Orientation Using "people power", the "5th P", European Journal of Marketing, Vol.: 37, Issue: 10, p.1301- 1313.

[22] Kotler, Philip., and Amstrong, (2001), Principle of Marketing, New York: Prentice Hall International Inc. A Division of Simon \& Scuster, Englewood Cliffs.

[23] Kotler, Philip., and Fox, Karen F. A, (1995), Strategy Marketing for Educational Institutions, New Jersey: Prentice- Hall. Inc. Englewood Cliffs, Second Edition, 1995.

[24] Kotler, Philip and Keller Kevin L. (2016). MARKETING MANAGEMENT, Fiveteenth Edition, Horizon Edition, England PEARSON Education Linited.

[25] Li, Chung- Kai., and Hung, Chia- Hung, (2009), "Marketing Tactics and Parent's Loyalty: The mediating Role of School Image", Journal of Educational Administration, Vol.: 47, Issue: 4, p. 477- 489.

[26] Li, Yanchen., Chou, Ting- Jui and Xingquan, Yan, (2009), "The Effect of Service Quality and Opprtunistic Behavior on Customer Share and Future Intentions in Business Market: The Pivotal Role of Trust", School of Economic and Management, Southwest Jiaotong University, China.

[27] Lovelock, Christopher., and Wright, Lauren K, ( 2005), Manajemen Pemasaran Jasa, Jakarta: PT INDEKS Kelompok Gramedia, Edisi Bahasa Indonesia.

[28] Lovelock, Christopher et al. (2012). Pemasaran Jasa, Manusia, Teknologi, Strategi, Perspektif Indonesia, Jilid2, Edisi Ketujuh. Jakarta. Penerbit ERLANGGA 
[29] Lupiyoadi, Rambat., dan Hamdani, A, (2006), Manajemen Pemasaran Jasa, Jakarta: Salemba Empat, Edisi 2, 2006.

[30] Ndubisi, Nelson Oly, (2007), "Relationship Marketing and Customer Loyalty", Journal Marketing Intellegence \& Planning, Vol.: 25, Issue: 1, p.98- 106.

[31] Nguyen, Na., and LeBlanc, Gaston, (1998), "The Mediating Role of Corporate Image on Customer's Retention decisions: an Investigation in Financial Service", International Journal of Bank Marketing, Vol.: 16, Issue: 2, p. 52- 65.

[32] Pratisto, Arif, (2004), Cara Mudah Mengatasi Masalah Statistik dan Rancangan Percobaan dengan SPSS 12, Jakarta: PT Elex Media Komputindo, Kelompok Gramedia.

[33] Rosenberg, Larry J., and Czepiel, John A, (1984), "A Marketing Approach for Customer Retention", Journal of Customer Marketing, Vol.: 1, Issue: 2, p.45- 51.

[34] Russel, Marilyn, (2005), "Marketing Education: A Review of Service Quality Perseptions Among International Student", International Journal of Contemporary Hospitality Management, Vol.: 17, Issue: 1, p. 65- 77.

[35] Ruyter, Ko de., and Wetzel, Marten, (2000), "The Role of Corporate Image and extention Similarity in Service Brand Extention", Journal of Economic Psychology, 21 (2000), p.438- 469.

[36] Stimac, Helena; Simic, Mirna Leko. (2012), "COMPETITIVENESS IN HIGHER EDUCATION: A NEED FOR MARKETING ORIENTATION AND SERVICE QUALITY”, Economics \& Sociology 5.2 : 23-34,153.

[37] Sutojo, Siswanto, (2004), Membangun Citra Perusahaan, Sebuah Sarana Keberhasilan Pemasaran, Jakarta: PT Damar Mulia Pustaka.

[38] Viacava, Keitiline Ramos and Pedrozo, Eugenio Avila. (2010)." Higher Education in management: reinventing the paradigm to gain the capacity to handle today's complexity", On the Horizon, Vol.18 Iss:1, pp.45- 52.

[39] Wright, Robert E. (2012), "Marketing Orientations and Higher Education: Applications and Implications", The Journal of Applied Business and Economics, Volume .13, Issue . 5, pp. 53-57.

[40] Yulius, Yudi, (2004), "Pengaruh Bauran Pemasaran Jasa Pendidikan Terhadap Citra Perguruan Tinggi Swasta serta Implikasinya terhadap Jumlah Mahasiswa Aktif', Ph.D Dissertation, Universitas Padjajaran. 